\title{
主軸頭テーブル旋回形5軸制御マシニングセンタの 幾何偏差同定方法の一般化*
}

堤 正 臣 ${ }^{* 1}$, 深山 直記 ${ }^{* 2}$, 崔 成 日 $^{* 3}$, 佐伯 智之 ${ }^{* 4}$, 齋藤 明徳 ${ }^{* 5}$

\section{Generalization of Identification Method of Geometric Deviations for Mixed Type Five-Axis Machining Centres}

\author{
Masaomi TSUTSUMI*1, Naoki MIYAMA, Chengri CUI, \\ Tomoyuki SAIKI and Akinori SAITO
}

\footnotetext{
*1 Tokyo University of Agriculture and Technology, Dept. of Mechanical Systems Engineering 2-24-16, Nakacho, Koganei Tokyo, 184-8588 Japan
}

This paper proposes a general method for measuring and identifying the geometric deviations inherent to five axis machining centers with a swivel angular head and a rotary table. The structural configuration of this machine is one of mixed five-axis machining centers. If the inclination angle of $\mathrm{C}$ axis is an initial value and its angular deviation is also superimposed on it, the inherent geometric deviations are same as multi-tasking machines, which have ten inherent deviations. The circular motion of simultaneous four-axis control around the tilt $\mathrm{C}$-axis is newly proposed in order to measure the circular trajectories and its eccentricities. The measurement of simultaneous three-axis motion around the B-axis is also required to identify the inherent deviations. In this paper, mathematical relationships between geometric deviations and eccentricities of the trajectories are derived and then the procedure for identifying the deviations using the expressions was clarified through numerical experiments. It is also pointed out that six measurements are needed to identify the inherent deviations when the inclination is zero.

Key Words : Five-Axis Control, Angular Swivel Head, Geometric Deviation, Ball Bar, Mathematical Expression

\section{1. 緒言}

エネルギー機器の製造用として注目されている 5 軸制御マシニングセンタに主軸頭とテーブルとに旋回機構を もつ主軸頭テーブル旋回形（以下，混合形 5 軸 MC という。）がある。これは，旋削を必要とする比較的大きな 製品の加工に適している．この機械の制御軸構成は旋盤形複合加工機と同じで，主軸頭の旋回のさせ方で 3 種類 に分類できる. 主軸頭が前後方向, 左右方向に旋回するものと, 主軸頭が 45 傾いた面内で旋回するものである.

主軸頭が前後に旋回するものと左右に旋回するものに共通していることは，旋回軸が直交軸と平行なことであ る.これらの機械については，いずれもボールバーを用いて旋回 1 軸と直進 2 軸との同時 3 軸制御運動を測定す れば，運動軸間の直角度などを評価することができる(1). しかし，傾斜した面内で旋回する主軸頭をもつ機械の 場合には，すでに求めた旋盤形複合加工機の近似式(1)をそのまま適用することはできない. 同時 3 軸制御によっ

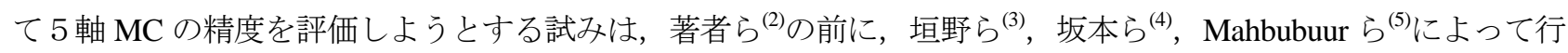
われたが，最近行われたボールバーを使った同種の研究(6) (10)でもこの形態の精度評価を扱ったものはない.

混合形 5 軸 MC の場合に, 傾斜した軸の回転に同期させて, 工具-工作物間の距離が一定になるように直交軸を

\footnotetext{
*原稿受付 2010 年 9 月 23 日

*1 正員, フェロー，東京農工大学大学院工学研究院 (广184-8588 東京都小金井市中町2-24-16)

*2 (株)ブリヂストン(テ329-3155 栃木県那須塩原市笹沼 370)

*3 三井精機工業 (株) (广T350-0193＼cjkstart埼玉県比企郡川島町八幡 6-13)

${ }^{* 4}$ 日本ファインテック (株) (广823-0015 福岡県宮若市上有木 1438-4)

*5正員，日本大学工学部（广963-8642＼cjkstart福島県郡山市田村町徳定字中河原1）

E-mail: tsutsumi@cc.tuat.ac.jp
} 
運動させるには，直交3 軸全てを制御しなければならない。このことは，すでに筆者らの報告 ${ }^{(11)}$ で示したように 同時 4 軸制御運動が必要になることを意味している.

ところが，混合形の場合には 5 軸 MC に固有の偏差の数がテーブル旋回形よりも多く(1)，テーブル旋回形に対 して求めた結果(2) (4),(12)をそのまま適用できない，そこで，本論文では主軸頭が任意の角度傾斜した面内で旋回す る混合形 5 軸 MC を対象として, 幾何偏差と軌跡の偏心量との一般的な関係式を導き, 数值実験によってその妥 当性を確認する．なお，ここで提案する測定方法は，ボールバーを使用することを前提としている.

\section{2. 座標系及び幾何モデル}

研究対象とする傾斜した旋回主軸頭をもつ 5 軸 MC の例を図 1(a)に示す.この機械は, 工作物側(w)から工具側 (t)までの軸構成を, ベッド(b)を考慮して表示すると, w-B'Z'bXYC-t と表現できる. ベッド上に直交座標系が載 っており， Z 軸の上にテーブルが，Y 軸の上に主軸頭がそれぞれ載っていることを表している．ただし，この例 に示す C 軸は垂直面に対して 45傾いている.

図 1(b)に旋回軸が直進軸と平行な一般の混合形 5 軸 MC の幾何偏差を示す. X, Y , Z の三つの直進軸間の偏差 以外の偏差が 5 軸 $\mathrm{MC}$ に固有の偏差であり，B 軸に関係する偏差と $\mathrm{C}$ 軸に関係する偏差の合計 10 個の幾何偏差 が存在する ${ }^{(1),(13)}$. 直交する三つの軸は, 真直であり，かつ，互いに直角で，その上に載せられたテーブル及び主 軸頭に偏差が存在するものとすると，座標軸を使って図 1(b)の誤差を定義すると図 2 のようになる．ここで $\delta_{x}$, $\delta_{y}, \delta_{z}$ は，それぞれ，X，Y， Z方向の位置の偏差を表し， $\alpha, \beta, \gamma$ は， $\mathrm{X}, \mathrm{Y}, \mathrm{Z}$ 軸周りの角度偏差を表している. 二つの大文字の添え字は，主軸を含む座標系を表しており，例えば， $\delta_{x C S}$ は， C 軸座標系の原点と $\mathrm{S}$ 軸（主軸） 座標系の原点との $\mathrm{X}$ 方向の位置偏差であり， $\alpha_{Y C}$ は， $\mathrm{C}$ 軸の $\mathrm{X}$ 軸周りの角度偏差，すなわち， $\mathrm{C}$ 軸と $\mathrm{Y}$ 軸との直

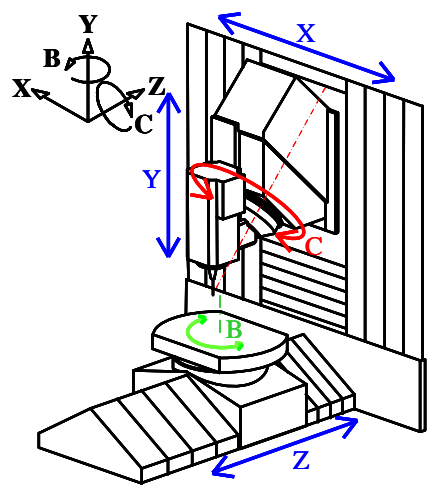

(a) Five-axis machining center used for case study

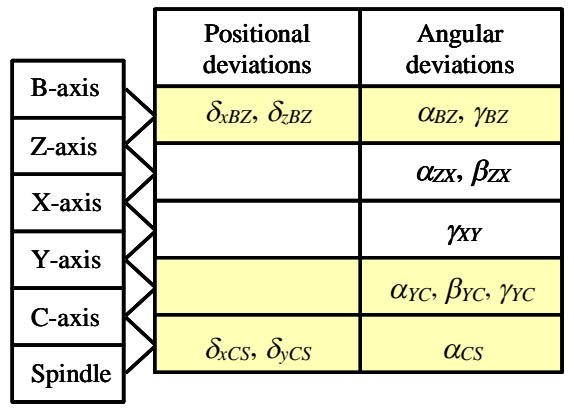

(b) Geometric deviations in a conventional mixed type five-axis machining center

Fig.1 Five-axis machining center with a swivel angular head (w-B' Z' bXYC-t)

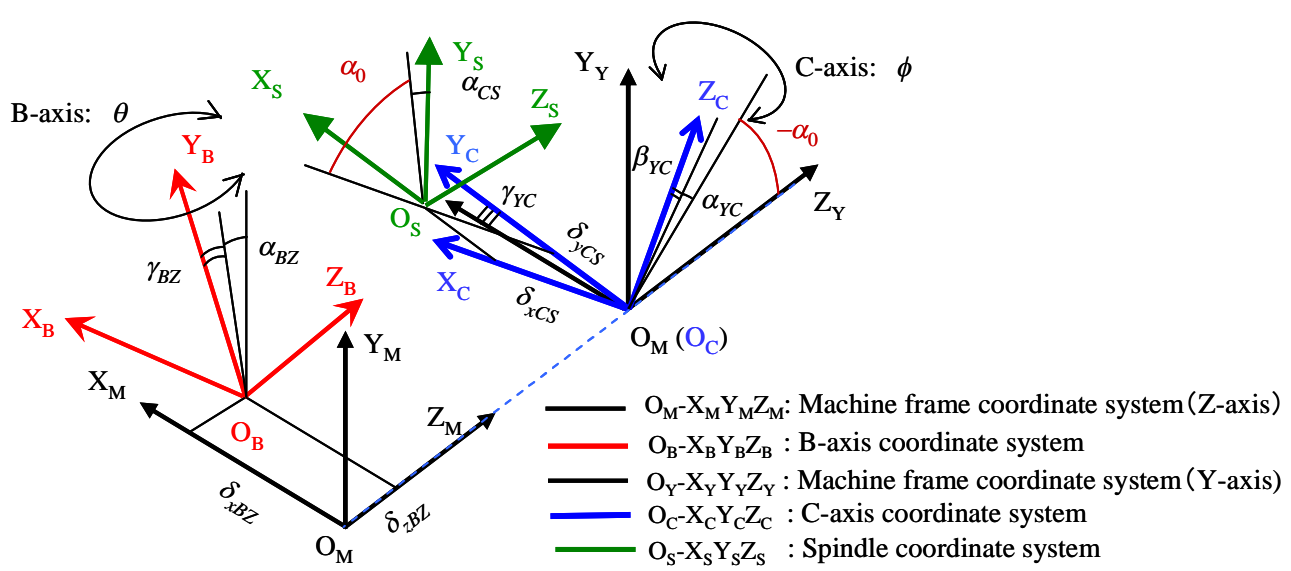

Fig. 2 Coordinate system and definition of geometric deviations 


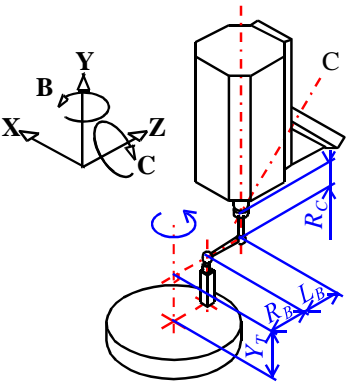

(a) Radial

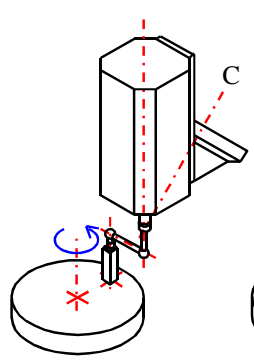

(b) Tangential

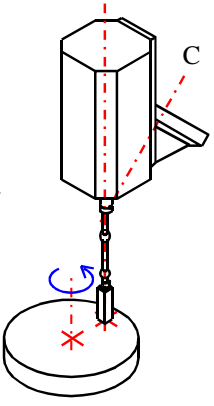

(c) Axial

Fig.3 Sensitive direction of ball bar in simultaneous 3-axis motion of $\mathrm{X}, \mathrm{Y}$ and $\mathrm{B}$ axes

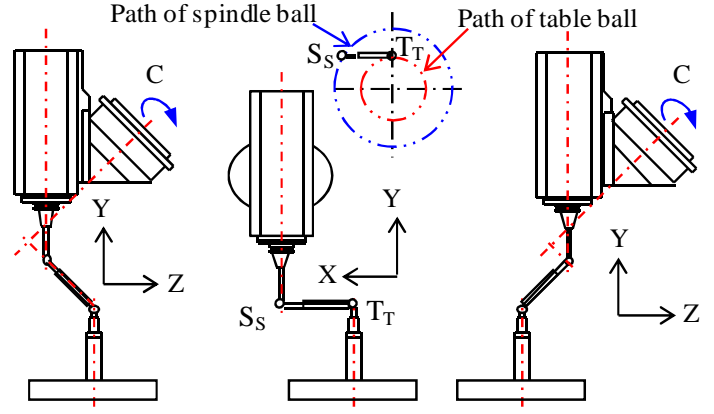

$\begin{array}{lll}\text { (a) Radial } & \text { (b) Tangential }\end{array}$

(c) Axial

Fig.4 Sensitive direction of ball bar in simultaneous 4-axis motion of $\mathrm{X}, \mathrm{Y}, \mathrm{Z}$ and $\mathrm{C}$ axes

角度偏差を表す。また, 角度偏差 $\alpha_{Z X}, \beta_{Z X}, \gamma_{X Y}, \gamma_{B Z}$ は，それぞれ $\mathrm{Z}$ 軸の $\mathrm{X}$ 軸周り, $\mathrm{Z}$ 軸の $\mathrm{Y}$ 軸周り, $\mathrm{Y}$ 軸の $\mathrm{Z}$ 軸周り, B 軸の $Z$ 軸周りの角度偏差を表している。このうち角度偏差 $\alpha_{Z X}, \beta_{Z X}, \gamma_{X Y}$ は, 直交 3 軸間の直角度偏差 で，例えば $\mathrm{X}$ 軸と $\mathrm{Y}$ 軸との間に角度偏差 $\gamma_{X Y}$ が存在してもこれら 2 軸による円弧補間運動軌跡が $45^{\circ}$ 傾いた長円 になるだけで中心位置は変化しない，そこでこれらの偏差を除く 10 個の偏差の同定方法について検討する.

ここで, 本研究の解析対象としている構造形態をもつ機械の特異な点は, 主軸頭を旋回させる軸（C 軸）が, 傾いていることである.この特異な形態を著者らがいままで取り組んできたように数学的に扱うために， C 軸の 傾斜角度を $\alpha_{0}$ とし, 主軸と $\mathrm{C}$ 軸との角度偏差 $\alpha_{C S}$ 及び $\mathrm{C}$ 軸と $\mathrm{Y}$ 軸との角度偏差 $\alpha_{Y C}$ にそれぞれ初期值として $\alpha_{0}$ と - $\alpha_{0}$ とを与え，この 5 軸 MC を表現できるものと仮定する．なお，これと同じ考え方は，テーブル側に傾斜軸を もつ 5 軸 MCについて適用し, 妥当性を確認している(11).

\section{3. ボールバーを用いた同時制御運動}

\section{$3 \cdot 1$ 同時 3 軸及び同時 4 軸制御運動}

本研究では, いままで直交する旋回軸をもつ 5 軸 MC 用に開発してきた測定方法をこの混合形 5 軸 MCにも適 用する. 図 3 に B 軸回転に対する半径方向, 接線方向及び軸方向の運動を示寸. 同図(a)には, 記号の定義も示し てある. ここで， $Y_{T}$ はテーブル側球の中心とテーブル上面との距離， $R_{C}$ は傾斜 $\mathrm{C}$ 軸と主軸中心線との交点から 主軸側球中心までの距離, $R_{B}$ はテーブル中心線とテーブル側球との距離, $L_{B}$ はボールバーの基準長さである. 図 4 は C 軸回転に対する三つの方向の運動を示す，C軸は直交していないために, 傾斜した C 軸に直角に回転する 面に対してボールバーを三つの方向で追従させようとすると二つの直進軸の円弧補間運動では不十分で，X，Y，

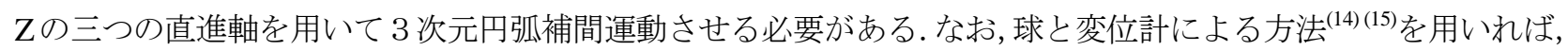
三つの運動は同時に測定できる.

\section{$3 \cdot 2$ 指令值の作成方法}

図 2 に示寸数学モデル上で主軸座標系における主軸側球の座標 $S_{S}$ を, $\mathrm{C}$ 軸の回転角及び $\mathrm{C}$ 軸の傾き角を考慮し て機械座標系における座標 $S_{M C}$ に変換する. テーブル側においては, テーブル座標系における主軸側球の座標 $S_{T}$ を, B 軸の回転角を考慮に入れて機械座標系における座標 $S_{M B}$ に変換する. そもそも同時 4 軸制御運動において $S_{M C}$ と $S_{M B}$ は一致するので, これらの差分が各直進軸に与える指令值となる.

(1) 主軸座標系から C 軸座標系への変換まず, 主軸座標系における主軸側球の座標 $S_{S}\left(x_{S S}, y_{S S}, z_{S S}\right)$ を, C 軸 座標系における座標 $S_{C}\left(x_{S C}, y_{S C}, z_{S C}\right)$ に変換する. 機械座標系と $\mathrm{C}$ 軸座標系の間には角度偏差の初期值として $\alpha_{C S}=\alpha_{0}$ が存在するので, その回転マトリックス $D_{\alpha C S}$ は, 式(1)のように表せる.

$$
D_{\alpha C S}=\left[\begin{array}{ccc}
1 & 0 & 0 \\
0 & \cos \alpha_{0} & -\sin \alpha_{0} \\
0 & \sin \alpha_{0} & \cos \alpha_{0}
\end{array}\right]
$$


したがって， $S_{C}$ は，式(1)を用いて次のように表せる.

$$
S_{C}=D_{\alpha C S} S_{S}
$$

(2) $\mathrm{C}$ 軸座標系から機械座標系への変換 次に, $S_{C}$ を機械座標系における座標 $S_{M C}\left(x_{S M}, y_{S M}, z_{S M}\right)$ に変換する. C 軸座標系と機械座標系との間には角度偏差の初期値として $\alpha_{Y C}=-\alpha_{0}$ が存在する. また, C 軸座標系は, 機械座標 系に対し $\mathrm{Z}$ 軸周りに角度 $\phi$ 回転することから, それらの回転マトリックス $D_{\alpha Y C}$ 及び $E_{C M}$ は, 次のように表せる.

$$
\begin{aligned}
D_{\alpha Y C} & =\left[\begin{array}{ccc}
1 & 0 & 0 \\
0 & \cos \left(-\alpha_{0}\right) & -\sin \left(-\alpha_{0}\right) \\
0 & \sin \left(-\alpha_{0}\right) & \cos \left(-\alpha_{0}\right)
\end{array}\right] \\
E_{C M} & =\left[\begin{array}{ccc}
\cos \phi & -\sin \phi & 0 \\
\sin \phi & \cos \phi & 0 \\
0 & 0 & 1
\end{array}\right]
\end{aligned}
$$

したがって， $S_{M C}$ は，式(3)と式(4)から次式のようになる.

$$
S_{M C}=D_{\alpha Y C} E_{C M} S_{C}
$$

(3) テーブル座標系から機械座標系への変換 テーブル座標系における主軸側球の座標 $S_{T}\left(x_{S T}, y_{S T}, z_{S T}\right)$ を, 機械 座標系における座標 $S_{M B}\left(x_{S M}, y_{S M}, z_{S M}\right)$ に変換する. テーブル座標系は, 機械座標系に対し Y 軸周りに角度 $\theta$ 回転す ることから，その回転マトリックス $E_{B M}$ は，次のように表せる.

$$
E_{B M}=\left[\begin{array}{ccc}
\cos \theta & 0 & \sin \theta \\
0 & 1 & 0 \\
-\sin \theta & 0 & \cos \theta
\end{array}\right]
$$

したがって， $S_{M B}$ は，式(6)から次式のように表せる.

$$
S_{M B}=E_{B M} S_{T}
$$

同時 4 軸制御運動において $S_{M C}$ と $S_{M B}$ とは一致する.これらの差分が $S_{M C}$ と $S_{M B}$ とを一致させるために動かさな くてはならない直進軸の変位量, 寸なわち指令值である. したがって, 指令值 $S\left(x_{S}, y_{S}, z_{s}\right)$ は, 次のように表せる.

$$
S=S_{M B}-S_{M C}
$$

\section{4. シミュレーション}

\section{$4 \cdot 1$ シミュレーション方法}

シミュレーションでは，5 軸 MC に存在する幾何偏差と各軸の動作とを図 2 に示すようなモデルで表現し，同 時 4 軸制御運動におけるボールバーの 2 球の中心座標を機械座標系で求めた。 なお, 運動開始時の 2 球間の距離 がボールバーの基準長さに一致するようにテーブル側球を取り付けるものとし, 取付け誤差を考慮に入れたもの となっている. 2 球間の距離の変化は極座標形式で表し, 半径方向に拡大して表示寸る.

(1) 主軸座標系から $\mathbf{C}$ 軸座標系への変換 まず, 主軸座標系における主軸側球の座標 $S_{S}\left(x_{S S}, y_{S S}, z_{S S}\right)$ を, C 軸座 標系における座標 $S_{C}\left(x_{S C}, y_{S C}, z_{S C}\right)$ に変換する. 機械座標系と C 軸座標系の間には角度偏差 $\alpha_{C S}\left(+\right.$ 初期值 $\left.\left(\alpha_{0}\right)\right)$ 及び 位置偏差 $\delta x_{C S}, \delta y_{C S}$ が存在する. それらの回転マトリックス $D_{\alpha C S}$ 及び位置偏差の行列 $D_{\delta C S}$ は, 次のように表せる.

$$
\begin{aligned}
D_{\alpha C S} & =\left[\begin{array}{ccc}
1 & 0 & 0 \\
0 & \cos \left(\alpha_{C S}+\alpha_{0}\right) & -\sin \left(\alpha_{C S}+\alpha_{0}\right) \\
0 & \sin \left(\alpha_{C S}+\alpha_{0}\right) & \cos \left(\alpha_{C S}+\alpha_{0}\right)
\end{array}\right] \\
D_{\delta C S} & =\left[\begin{array}{c}
\delta x_{C S} \\
\delta y_{C S} \\
0
\end{array}\right]
\end{aligned}
$$


したがって， $S_{C}$ は，これらの回転マトリックスと位置偏差の行列を用いて次のように表せる.

$$
S_{C}=D_{\alpha C S} S_{S}+D_{\delta C S}
$$

(2) $\mathbf{C}$ 軸座標系から機械座標系への変換 次に, $S_{C}$ を機械座標系における座標 $S_{M}\left(x_{S M}, y_{S M}, z_{S M}\right)$ に変換する. C 軸座標系と機械座標系の間には角度偏差 $\alpha_{Y C}\left(+\right.$ 初期值 $\left.\left(-\alpha_{0}\right)\right), \beta_{Y C}, \gamma_{Y C}$ が存在する. また, C 軸座標系は機械座 標系に対し Z 軸周りに $\phi$ 回転することから, それらの回転マトリックス $D_{\alpha Y C}, D_{\beta Y C}, E_{C M}$ は, 次のように表せる.

$$
\begin{aligned}
D_{\alpha Y C} & =\left[\begin{array}{ccc}
1 & 0 & 0 \\
0 & \cos \left(\alpha_{Y C}-\alpha_{0}\right) & -\sin \left(\alpha_{Y C}-\alpha_{0}\right) \\
0 & \sin \left(\alpha_{Y C}-\alpha_{0}\right) & \cos \left(\alpha_{Y C}-\alpha_{0}\right)
\end{array}\right] \\
D_{\beta Y C} & =\left[\begin{array}{ccc}
\cos \beta_{Y C} & 0 & \sin \beta_{Y C} \\
0 & 1 & 0 \\
-\sin \beta_{Y C} & 0 & \cos \beta_{Y C}
\end{array}\right] \\
E_{C M} & =\left[\begin{array}{ccc}
\cos \left(\phi+\gamma_{Y C}\right) & -\sin \left(\phi+\gamma_{Y C}\right) & 0 \\
\sin \left(\phi+\gamma_{Y C}\right) & \cos \left(\phi+\gamma_{Y C}\right) & 0 \\
0 & 0 & 1
\end{array}\right]
\end{aligned}
$$

したがって， $S_{M}$ は，式(12)〜(14)から次式で表せる.

$$
S_{M}=D_{\alpha Y C} D_{\beta Y C} E_{C M} S_{C}
$$

(3) テーブル座標系から機械座標系への変換テーブル座標系におけるテーブル側球の座標 $T_{T}\left(x_{T T}, y_{T T}, z_{T T}\right)$ を, 機械座標系における座標 $T_{M}\left(x_{T M}, y_{T M}, z_{T M}\right)$ に変換する. テーブル座標系と機械座標系との間には角度偏差 $\alpha_{B Z}, \gamma_{B Z}$ 及び位置偏差 $\delta_{x B Z}, \delta_{z B Z}$ が存在する. また, テーブル座標系は, 機械座標系に対し Y 軸周りに角度 $\theta$ 回転すること から, 回転マトリックス $D_{\alpha B Z}, D_{\gamma B Z}, E_{B M}$ 及び位置偏差の行列 $D_{\delta B Z}$ は, 次のように表せる.

$$
\begin{aligned}
D_{\alpha B Z} & =\left[\begin{array}{ccc}
1 & 0 & 0 \\
0 & \cos \alpha_{B Z} & -\sin \alpha_{B Z} \\
0 & \sin \alpha_{B Z} & \cos \alpha_{B Z}
\end{array}\right] \\
D_{\gamma B Z} & =\left[\begin{array}{ccc}
\cos \gamma_{B Z} & -\sin \gamma_{B Z} & 0 \\
\sin \gamma_{B Z} & \cos \gamma_{B Z} & 0 \\
0 & 0 & 1
\end{array}\right] \\
E_{B M} & =\left[\begin{array}{ccc}
\cos \theta & 0 & \sin \theta \\
0 & 1 & 0 \\
-\sin \theta & 0 & \cos \theta
\end{array}\right] \\
D_{\delta B Z} & =\left[\begin{array}{c}
\delta_{x B Z} \\
0 \\
\delta_{z B Z}
\end{array}\right]
\end{aligned}
$$

したがって， $T_{M}$ は，これらの回転マトリックスと位置偏差の行列を用いて，次のように表せる.

$$
T_{M}=D_{\alpha B Z} D_{\gamma B Z} E_{B M} T_{T}+D_{\delta B Z}
$$

$T_{M}\left(x_{T M}, y_{T M}, z_{T M}\right)$ と $S_{M}\left(x_{S M}, y_{S M}, z_{S M}\right)$ とから, 2 球間の距離 $L$ を求める. $L$ とボールバー基準長さ $L_{B}$ との差がボー ルバーの伸縮量 $\Delta L$ になる.

$$
\Delta L=\sqrt{\left(x_{S M}-x_{T M}\right)^{2}+\left(y_{S M}-y_{T M}\right)^{2}+\left(z_{S M}-z_{T M}\right)^{2}}-L_{B}
$$

なお，球と変位計とを用いる方法 ${ }^{(14),(15)}$ であれば， $L_{B}$ は，球の直径になる. 


\section{$4 \cdot 2$ 取付け誤差}

テーブル旋回形では前節に示した方法で偏心量を求めるシミュレーションを行うことができた。しかし，テー ブル旋回形で問題にならなかったテーブル側球の取付け誤差が, 混合形 5 軸 MC で偏心量として影響を及ぼすこ とがわかっている(1).

そこで，実際の測定手順に従って取り付けた場合のテーブル側球の位置を，主軸座標系からテーブル座標系へ の座標変換によって求め, この位置をテーブル座標系におけるテーブル側球の初期位置とすることにした.

(1) 主軸座標系から C 軸座標系への変換 まず, 主軸座標系における主軸側球の座標 $S_{S}\left(x_{S S}, y_{S S}, z_{S S}\right)$ を, C 軸座 標系における座標 $S_{C}\left(x_{S C}, y_{S C}, z_{S C}\right)$ に変換する. 機械座標系と $\mathrm{C}$ 軸座標系との間には角度偏差 $\alpha_{C S}\left(+\right.$ 初期值 $\left.\left(\alpha_{0}\right)\right)$ 及 び位置偏差 $\delta_{x C S}, \delta_{y C S}$ が存在し，それらの回転マトリックス $D_{\alpha C S}$ 及び位置偏差の行列 $D_{\delta C S}$ は, 式(9), (10)のよう に表せた，したがって， $S_{C}$ は，式(9)，(10)を用いて次のように表せる.

$$
S_{C}=D_{\alpha C S} S_{S}+D_{\delta C S}
$$

(2) $\mathbf{C}$ 軸座標系から機械座標系への変換 次に, $S_{C}$ を機械座標系における座標 $S_{M}\left(x_{S M}, y_{S M}, z_{S M}\right)$ に変換する. C 軸座標系と機械座標系の間には角度偏差 $\alpha_{Y C}\left(+\right.$ 初期值 $\left.\left(-\alpha_{0}\right)\right), \beta_{Y C}, \gamma_{Y C}$ が存在し, それらの回転マトリックス $D_{\alpha Y C}$, $D_{\beta Y C}, E_{C M}$ は，式(12) (14)のように表せた。 ただし，C軸を回転させないので， $E_{C M}$ において C 軸回転角を除いた $D_{\gamma Y C}$ を用いることにする.

$$
D_{\gamma Y C}=\left[\begin{array}{ccc}
\cos \gamma_{Y C} & -\sin \gamma_{Y C} & 0 \\
\sin \gamma_{Y C} & \cos \gamma_{Y C} & 0 \\
0 & 0 & 1
\end{array}\right]
$$

したがって， $S_{M}$ は，式(12)，(13)，(23)を用いることによって次のように表せる.

$$
S_{M}=D_{\alpha Y C} D_{\beta Y C} D_{\gamma Y C} S_{C}
$$

(3) テーブル側球初期位置への移動 以上 2 回の座標変換によって機械座標系における主軸側球の座標が求め られた．実際の測定では, 以上の誤差を含んだまま, テーブル側球を取り付ける位置まで直進軸を動かすことに なる. なお, 同時 4 軸制御運動の旋回させる軸によって, このとき動かす值は異なってくる. 移動後の座標を $S^{\prime}{ }_{M}$ とすると, $S_{M}^{\prime}$ は, 次のように表せる.

$$
\begin{array}{ll}
\mathrm{C} \text { 軸旋回運動 : } & S_{M}^{\prime}=S_{M}+\left[\begin{array}{c}
0 \\
R_{C}+Y_{T} \\
0
\end{array}\right] \\
\text { B 軸旋回運動 : } & S_{M}^{\prime}=S_{M}+\left[\begin{array}{c}
0 \\
R_{C}+Y_{T} \\
R_{B}
\end{array}\right]
\end{array}
$$

(4) 機械座標系からテーブル座標系への変換 最後に, $S_{M}^{\prime}$ をテーブル座標系における座標 $S_{T}\left(x_{S T}, y_{S T}, z_{S T}\right)$ に変 換する. テーブル座標系と機械座標系の間には角度偏差 $\alpha_{B Z}, \gamma_{B Z}$ 及び位置偏差 $\delta_{x B Z}, \delta_{z B Z}$ が存在し, それらの回転 マトリックス $D_{\alpha B Z}, D_{\gamma B Z}$ 及び位置偏差の行列 $D_{\delta B Z}$ は，式(16)，(17)，(19)のように表せた．したがって， $S_{T}$ は, 式 (16)，(17)，(19)を用いて次のように表せる.

$$
S_{T}=D_{\gamma B Z}^{-1} D_{\alpha B Z}^{-1}\left(S_{M}^{\prime}-D_{\delta B Z}\right)
$$

実際の測定においては，このようにして求められる $S_{T}$ を基準にテーブル側球を取り付け，テーブル座標系にお けるテーブル側球の座標 $T_{T}\left(x_{T T}, y_{T T}, z_{T T}\right)$ とする. そのため, 本来取り付けられるべき位置からずれてしまうことが ある.これがテーブル側球の取付け誤差 ${ }^{(1)}$ であり, ボールバーの測定結果である軌跡の偏心量にも影響を及ぼす.

\section{$4 \cdot 3$ 円弧軌跡に及ぼすピッチ誤差の影響}

$\mathrm{C}$ 軸の傾斜角度を $\alpha_{0}=45^{\circ}$ とし, その他測定に必要な寸法を, 図3に定義した記号を用いて, $Y_{T}=200 \mathrm{~mm}$ (テ ーブル側球の中心とテーブル上面との距離)， $R_{C}=100 \mathrm{~mm}$ (主軸端面と主軸側球中心との距離), $R_{B}=100 \mathrm{~mm}$ (テ 


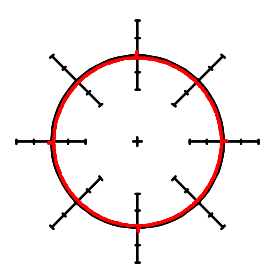

(i) C-axis Radial

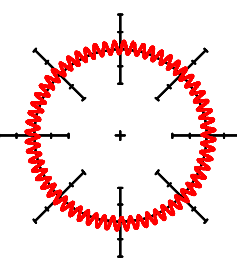

(ii) C-axis Tangential

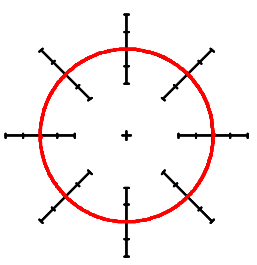

(iii) C-axis Axial

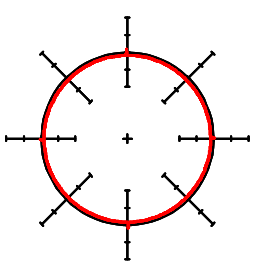

(iv) B-axis Radial

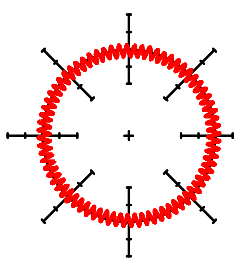

(v) B-axis Tangential

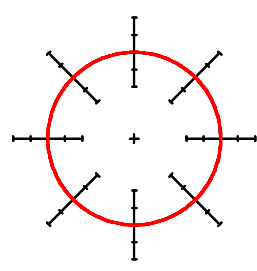

(vi) B-axis Axial

Fig.5 Influences of pitch error on circular trajectories

ーブル中心線とテーブル側球との距離)， $L_{B}=100 \mathrm{~mm}$ (ボールバーの基準長さ）としてシミュレーションを行っ た.このシミュレーションでは幾何偏差は存在しないものとし, 旋回軸は, ウオームギア駆動が多いことから C

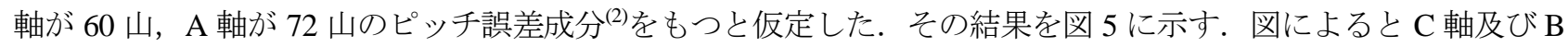
軸の接線方向をボールバーの感度方向としたときには，ピッチ誤差の影響が大きく現れているが，その他の方向 にはその影響は現れないことがわかる．筆者らは，ピッチ誤差が含まれると幾何偏差を同定したときにその誤差 が大きくなることを指摘している(16).

\section{$4 \cdot 4$ 円弧軌跡に及ぼす幾何偏差の影響}

$\alpha_{0}=45^{\circ}, Y_{T}=200 \mathrm{~mm}, R_{C}=100 \mathrm{~mm}, R_{B}=100 \mathrm{~mm}, L_{B}=100 \mathrm{~mm}$ としたときの円弧軌跡に及ぼす幾何偏差の影 響をシミュレーションした。 このシミュレーションではピッチ誤差を考慮していない. その結果を基準円からの 偏差として図 6 に示寸. 位置偏差として $\pm 10 \mu \mathrm{m}$, 角度偏差として $0.005^{\circ}$ 与えた. 図示した円弧軌跡において, 赤の実線が正の偏差を与えたときの結果，青の破線が負の偏差を与えたときの結果を表す．図は，円弧軌跡のう ち偏心しないで半径だけが変化する軌跡及びまったく変化しない軌跡については空白にしてある.

図によると，二つの偏差が影響するだけのもの，四つの偏差が影響するもの，及び全ての偏差が影響するもの の 3 とおりが存在する. この二つの偏差が影響するだけの C 軸と B 軸の軸方向の円弧軌跡からわかることは, 軸 方向運動の円弧軌跡には，それぞれの回転軸の直角度誤差の影響だけが反映しており，その他八つの偏差は影響 しないことである. 四つの偏差が影響する円弧軌跡は，いずれも $\mathrm{C}$ 軸の半径方向と接線方向の軌跡であるが，上 下の図をよく見ると，偏心の方向が異なっていることがわかる．例えば， $\alpha_{C S}$ の場合には $\mathrm{C}$ 軸半径方向では，X 方向に偏心し， C 軸接線方向では $\mathrm{Y}$ 方向に偏心寸る. 同様のことが，残りの三つの偏差についてもいえる.

\begin{tabular}{|c|c|c|c|c|c|c|c|c|c|c|}
\hline Deviations & $\begin{array}{l}\alpha_{C S}= \\
\quad \pm 0.005^{\circ} \\
\end{array}$ & $\begin{array}{l}\alpha_{Y C}= \\
\pm 0.005^{\circ}\end{array}$ & $\begin{array}{c}\beta_{Y C}= \\
\pm 0.005^{\circ}\end{array}$ & $\begin{array}{l}\gamma_{Y C}= \\
\pm 0.005^{\circ}\end{array}$ & \begin{tabular}{|c|}
$\alpha_{B Z}=$ \\
$\pm 0.005^{\circ}$ \\
\end{tabular} & $\begin{array}{c}\gamma_{B Z}= \\
\pm 0.005\end{array}$ & $\begin{array}{c}\delta_{x C S}= \\
\pm 10 \mu \mathrm{m} \\
\end{array}$ & $\begin{array}{c}\delta_{y c s}= \\
\pm 10 \mu \mathrm{m}\end{array}$ & $\begin{array}{c}\delta_{x B Z}= \\
\pm 10 \mu \mathrm{m}\end{array}$ & $\begin{array}{c}\delta_{z B Z}= \\
\pm 10 \mu \mathrm{m}\end{array}$ \\
\hline \multicolumn{11}{|l|}{$\begin{array}{l}\text { (i) } \begin{array}{l}\text { C-axis } \\
\text { Radial }\end{array}\end{array}$} \\
\hline \multicolumn{11}{|l|}{$\begin{array}{l}\text { (ii) C-axis } \\
\text { Tangential }\end{array}$} \\
\hline \multicolumn{11}{|l|}{$\begin{array}{l}\text { (iii)C-axis } \\
\text { Axial }\end{array}$} \\
\hline \multicolumn{11}{|l|}{$\begin{array}{l}\text { (iv)B-axis } \\
\text { Radial }\end{array}$} \\
\hline \multicolumn{11}{|l|}{$\begin{array}{l}\text { (v) B-axis } \\
\text { Tangential }\end{array}$} \\
\hline $\begin{array}{c}\text { (vi)B-axis } \\
\text { Axial }\end{array}$ & & & & & & & & & & \\
\hline & & & & & div.:20 um & 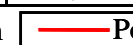 & sitive devi & & "Negative & deviation \\
\hline
\end{tabular}

Fig.6 Influences of geometric deviations on circular trajectories 
一方で, B 軸の半径方向と接線方向の軌跡には全ての偏差の影響が現れる. しかし, 図の(iv) と(v)とを比較する と, ボールバーの感度方向によって偏心の方向が異なる. なお, 同じ取付け条件で， $\alpha_{0}=0^{\circ}$ とすると， C 軸半径 及び接線方向運動における $\alpha_{C S}$ の偏心， $\mathrm{B}$ 軸半径及び接線方向運動における $\beta_{Y C}$ 及び $\delta_{y C S}$ の偏心は，いずれも現れ なくなることを確認している.

以上の結果に基づいて，従来から筆者らが行ってきた偏心量と幾何偏差との関係を近似式で表し，同定する方 法について検討する ${ }^{(1),(12)}$.

\section{5. 幾何偏差と近似式}

\section{$5 \cdot 1$ 偏心量と幾何偏差との関係式}

回転駆動機構のピッチ誤差の影響が大きく現れると，ピッチ誤差がない場合と比べて，円弧軌跡をもとに求め た偏心量に大きな誤差が生じることが分かっている. そこで, 接線方向を除いた半径方向及び軸方向の四つの運 動から，幾何偏差と偏心量との関係を求めることにした.

（1） $\mathbf{C}$ 軸半径方向 まず， C 軸の傾き角 $\alpha_{0}$ の值として $\alpha_{0}=45^{\circ}$ の場合について考える. 偏差 $\alpha_{C S}$ が存在した場合 のボールバー基準長さ $L_{B}$ との差 $\Delta L$ を式(9) (27)から計算すると，式(28)のようになる.

$$
\begin{aligned}
\Delta L=\left\{\left(L_{B}-0.5 \sqrt{2} R_{C} \sin \alpha_{C S} \cos \phi\right)\right)^{2}+\left(2 R_{C}^{2}+2 R_{C}^{2} \sin \alpha_{C S}+\sqrt{2} L_{B} R_{C}\right)(1-\cos \phi)\left(1-\cos \alpha_{C S}\right) & \\
& \left.-\frac{1}{2} R_{C}^{2}(1-\cos \phi) \sin ^{2} \alpha_{C S}\right\}^{\frac{1}{2}}-L_{B}
\end{aligned}
$$

式(28)において， $\alpha_{C S}$ が十分に小さい場合には，1- $1-\cos \alpha_{C S}=0$ 及び $\sin ^{2} \alpha_{C S}=0$ と近似できる. したがってこの式の 右辺の第 2 項と第 3 項とは省略でき， $\Delta L$ は，変数として式(29)のよう表すことができる.

$$
\Delta L=-\frac{\sqrt{2}}{2} R_{C} \sin \alpha_{C S} \cos \phi
$$

この式(29)は，周期が $360^{\circ}$ で，振幅が $\left|0.5 \sqrt{2} R_{C} \sin \alpha_{C S}\right|$ の余弦波を表しており，偏心量の一成分と考えることが できる，同様に偏差 $\gamma_{Y C} ， \delta_{x C S}, \delta_{y C S}$ が存在した場合の $\Delta L$ は，それぞれ次のようになる.

$$
\begin{aligned}
& \Delta L=\frac{\sqrt{2}}{2} R_{C} \sin \gamma_{Y C} \sin \phi \\
& \Delta L=\delta_{x C S} \sin \phi \\
& \Delta L=-\delta_{y C S} \cos \phi
\end{aligned}
$$

式(29), (32)と式(30), (31)とで, 位相が 90異なることから, 測定データの X 方向の偏心量 $e_{x}$ と Y 方向の偏心 量 $e_{y}$ について式(33), (34)が成り立つ.

$$
\begin{aligned}
& e_{x}=\frac{\sqrt{2}}{2} R_{C} \sin \gamma_{Y C}+\delta_{x C S} \\
& e_{y}=-\frac{\sqrt{2}}{2} R_{C} \sin \alpha_{C S}-\delta_{y C S}
\end{aligned}
$$

次に, $\mathrm{C}$ 軸の傾き角 $\alpha_{0}=30^{\circ}$ の場合について考える. $\alpha_{0}=45^{\circ}$ のときと同様に, 各偏差がそれぞれ存在した場合 の $\Delta L$ を求め, 測定データの X 万向の偏心量 $e_{x}$ と $\mathrm{Y}$ 方向の偏心量 $e_{y}$ についてまとめると式(35), (36)が得られる.

$$
\begin{aligned}
& e_{x}=\frac{\sqrt{3}}{2} R_{C} \sin \gamma_{Y C}+\delta_{x C S} \\
& e_{y}=-\frac{1}{2} R_{C} \sin \alpha_{C S}-\delta_{y C S}
\end{aligned}
$$

式(33)と式(35), 式(34)と式(36)との各項の係数比較を行って， $\alpha_{0}$ を用いて表すと式(37)，(38)のようになる.

$$
\begin{aligned}
& e_{x}=R_{C} \cos \alpha_{0} \sin \gamma_{Y C}+\delta_{x C S} \\
& e_{y}=-R_{C} \sin \alpha_{0} \sin \alpha_{C S}-\delta_{y C S}
\end{aligned}
$$


Table 1 Relationships between geometric deviations and eccentricities

\begin{tabular}{l|c|l|l|l}
\hline \multirow{2}{*}{} & \multicolumn{2}{|c|}{ C-axis } & \multicolumn{2}{c}{ Badial } \\
\cline { 2 - 5 }$\alpha_{C S}$ & $-R_{C} \sin \alpha_{0} \sin \alpha_{C S} \sin \phi$ & & \multicolumn{1}{c}{ Axial } & \multicolumn{1}{c}{ Axial } \\
\hline$\alpha_{Y C}$ & & $-R_{C} \cos \alpha_{0} \sin \alpha_{Y C} \cos \phi$ & $-R_{C} \sin \alpha_{Y C} \cos \theta$ & \\
\hline$\beta_{Y C}$ & & $-R_{C} \cos \alpha_{0} \sin \beta_{Y C} \sin \phi$ & $-R_{C} \sin \alpha_{0} \sin \beta_{Y C} \sin \theta$ & \\
\hline$\gamma_{Y C}$ & $R_{C} \cos \alpha_{0} \sin \gamma_{Y C} \cos \phi$ & & $R_{C} \cos \alpha_{0} \sin \gamma_{Y C} \sin \theta$ & \\
\hline$\alpha_{B Z}$ & & & $Y_{T} \sin \alpha_{B Z} \cos \theta$ & $R_{B} \sin \alpha_{B Z} \cos \theta$ \\
\hline$\gamma_{B Z}$ & & & $Y_{T} \sin \gamma_{B Z} \sin \theta$ & $-R_{B} \sin \gamma_{B Z} \sin \theta$ \\
\hline$\delta_{x C S}$ & $\delta_{x C S} \sin \phi$ & & $\delta_{x C S} \sin \theta$ & \\
\hline$\delta_{y C S}$ & $-\delta_{y C S} \cos \phi$ & & $-\delta_{y C S} \sin \alpha_{0} \cos \theta$ & \\
\hline$\delta_{x B Z}$ & & & $-\delta_{x B Z} \sin \theta$ & \\
\hline$\delta_{z B Z}$ & & & $-\delta_{z B Z} \cos \theta$ & \\
\hline
\end{tabular}

以上のように, $\mathrm{C}$ 軸半径方向で測定した軌跡から得られる偏心量と, 四つの幾何偏差との関係を導くことがで きた．同様にして，C 軸軸方向， $\mathrm{B}$ 軸半径方向及び $\mathrm{B}$ 軸軸方向について，一つずつの偏差に対する $\Delta L$ を求めた結 果を表 1 に示す。この表 1 と図 6 とは対応している. すなわち, 図 6 に示した軌跡をみると $\mathrm{C}$ 軸と B 軸の軸方向 では二つの偏差が影響しており，表 1 に示した式から，それぞれの偏心量と偏差との関係がよくわかる．また， $\mathrm{B}$ 軸半径方向の結果からも，全ての幾何偏差がどのように偏心量に影響を及ぼしているかもよくわかる．したが って, これらの関係式をもとに全ての偏差が, 軌跡の偏心量に及ぼす影響を評価することができる. この表に示 した結果をもとに，複数の正弦成分と余弦成分とをそれぞれ一つにまとめて，X方向，Y方向又は Z方向の偏心 量の関係として表すと，次のようになる.

(2) C 軸軸方向

$$
\begin{aligned}
& e_{x}=-R_{C} \cos \alpha_{0} \sin \beta_{Y C} \\
& e_{y}=-R_{C} \cos \alpha_{0} \sin \alpha_{Y C}
\end{aligned}
$$

(3) $\mathbf{B}$ 軸半径方向

$$
\begin{aligned}
& e_{x}=-R_{C} \sin \alpha_{0} \sin \beta_{Y C}+R_{C} \cos \alpha_{0} \sin \gamma_{Y C}+Y_{T} \sin \gamma_{B Z}+\delta_{x C S}-\delta_{y_{B Z}} \\
& e_{z}=-R_{C} \sin \alpha_{C S}-R_{C} \sin \alpha_{Y C}-Y_{T} \sin \alpha_{B Z}-\delta_{y_{C S}} \sin \alpha_{0}-\delta_{x B Z}
\end{aligned}
$$

(4) $\mathbf{B}$ 軸軸方向

$$
\begin{aligned}
& e_{x}=-R_{B} \sin \gamma_{B Z} \\
& e_{z}=R_{B} \sin \alpha_{B Z}
\end{aligned}
$$

以上示したように，円弧軌跡の偏心量と幾何偏差との関係を表す近似式を，旋回軸の傾斜角 $\alpha_{0}$ 考慮して表す ことができた．ここで求めた式は，全てボールバーの基準長さ $L_{B}$ に関係しないことから，ボールバーと同様の測 定ができる球と変位計とによる方法で得られた結果にも適用できる(14),(15). なお，球と変位計とによる方法の場合 の球の半径は，ボールバーの基準長さと同等である.

\section{$5 \cdot 2$ 同定手順}

同定手順は，図 6 及び表 1 からある程度推測できるが，以下にその手順を説明する.

(1) 手順 1: 図 6 に示すように C 軸軸方向では各軸方向の偏心量に $\alpha_{Y C}$ と $\beta_{Y C}$ が一つずつ影響している.そこで, $\mathrm{C}$ 軸軸方向の測定を行い, 得られた偏心量を式(39),(40)に代入して $\alpha_{Y C}$ と $\beta_{Y C}$ を求める.

(2) 手順 2: B 軸軸方向でも, 図 6 に示すように, 各軸方向の偏心量に $\alpha_{B Z}$ と $\gamma_{B Z}$ が一つずつ影響している. し たがって，B 軸軸方向で測定を行い，得られた偏心量を式(43)，(44)に代入して $\alpha_{B Z}$ と $\gamma_{B Z}$ を求める. なお，手 順 1 と 2 とは，変数が独立しているのでどちらを先に同定してもよい.

(3) 手順 3: 図 6 に示すように, C 軸半径方向では四つの偏差が影響するために，一つの条件で 1 回の測定を 
行うだけでは，これら四つの偏差を求めることはできない，式(37)と式(38)を見ると，角度偏差の項と位置偏 差の項とが独立してあることから，主軸端面から主軸頭側球の中心までの距離 $R_{C}$ を変えて測定を行えば，角 度偏差の項の值が変化するが, 位置偏差の項の值は変化しない. 従って, 2 通りの $R_{C}$ につて測定を行い, それぞれの偏心量を求め, 式(37)と式(38) とを用いて四つの式を連立させて， $\alpha_{C S}, \gamma_{Y C}, \delta_{x C S}$ 及び $\delta_{y C S}$ を求める. ただし， $\alpha_{0}=0^{\circ}$ のき式(38)からわかるように，Y 軸方向の偏心量に $\alpha_{C S}$ の影響は現れない. そのため, $\alpha_{C S}$ の 含まれている式(42)から, この段階では求めることができない.

(4) 手順 4: $\alpha_{0} \neq 0$ ののとき, $\alpha_{C S}$ は, 手順 3 で同定できているので, 10 個の偏差のうちの残りの $\delta_{x B Z}, \delta_{z B Z}$ は, すでに求めた偏差及び $\mathrm{B}$ 軸半径方向の測定から得られた偏心量を, 式(41)と式(42)とに代入して求めることが できる. しかし， $\alpha_{0}=0^{\circ}$ のき，手順 3 で述べたように $\alpha_{C S}$ を求めることができないために，三つの偏差 $\alpha_{C S}$, $\delta_{x B Z}, \delta_{z B Z}$ につては, 式(41)及び式(42)を使って同定することになる.この場合も, 連立方程式とするために, 主軸頭側球の中心から主軸端面までの距離 $R_{C}$ を変えて測定し, 得られた偏心量を用いて求めることになる. 以上のように， $\alpha_{0} \neq 0^{\circ}$ のときは，全ての偏差を 5 通りの測定から求めることができるが， $\alpha_{0}=0^{\circ}$ のきは， さらに条件を変えて測定を行い, 合計で 6 通りの測定が必要になる.

\section{6. 同定結果}

\section{$6 \cdot 1$ 機構解析ソフトウェア}

C 軸が傾斜した混合形 5 軸 MC の実機で測定ができないために，機構解析ソフト（DADS， ver. 9.60）を用いて 数值実験を行い, 提案した方法の妥当性を確認することにした. 具体的には, ソフトウェア上で任意の幾何偏差 を与え, 前章に示した手順に従って偏心量から偏差を求め, 与えた偏差と求めた偏差の差を求めた. DADS の計 算精度は 8 桁程度あり, その計算誤差はモデルから求める偏心量よりも小さい. したがって, 解析精度がシミュ レーション結果に及ぼす計算誤差の影響は無視できる程度に小さいと考えられる.

図 7 に機構解析ソフトで作成したモデルを示寸. このモデルでは主軸側球及びテーブル側球の 2 球間の距離の変 化を抽出できるようにしてある. 主軸頭の傾斜角 $\alpha_{0}$ は $45^{\circ}$ とし, ボールバーの取付け条件として, まずは, $Y_{T}=200$ $\mathrm{mm}, R_{B}=100 \mathrm{~mm}, R_{C}=100 \mathrm{~mm}, L_{B}=100 \mathrm{~mm}$ を与え, B 軸と C 軸の軸方向及び半径方向について計算し, 次に, $R_{C}$ だけを $R_{C}=150 \mathrm{~mm}$ に変えて，同様に計算した，表 2 の第 1 列に示寸 10 個の偏差をこのモデルに一度に与え て, 5・2 で提案した方法と手順とに従って偏差を求めた.

このとき数值実験で得られた偏心量を表 3 に示寸，偏心量は，表 3 に示すように， $R_{C}$ を 2 通りに変えて，計 5 通りの場合について求めた. これらの偏心量をもとに, $5 \cdot 2$ に示した手順に従って偏差を計算した. その結果

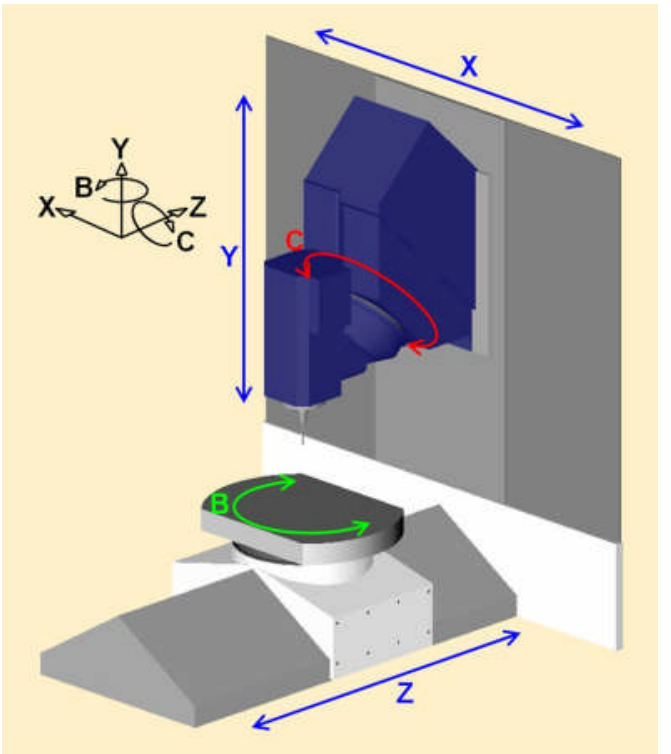

Fig.7 DADS model for simulation
Table 2 Geometric deviations given for DADS model and identified values

\begin{tabular}{c|r|r}
\hline $\begin{array}{c}\text { Geometric } \\
\text { deviations }\end{array}$ & $\begin{array}{c}\text { Given } \\
\text { values }\end{array}$ & $\begin{array}{c}\text { Identified } \\
\text { values }\end{array}$ \\
\hline$\alpha_{C S}\left(^{\circ}\right)$ & 0.005 & 0.0050 \\
\hline$\alpha_{Y C}\left(^{\circ}\right)$ & -0.007 & -0.0070 \\
\hline$\beta_{Y C}\left(^{\circ}\right)$ & 0.011 & 0.0110 \\
\hline$\gamma_{Y C}\left(^{\circ}\right)$ & -0.013 & -0.0130 \\
\hline$\alpha_{B Z}\left({ }^{\circ}\right)$ & 0.017 & 0.0169 \\
\hline$\gamma_{B Z}\left(^{\circ}\right)$ & -0.019 & -0.0190 \\
\hline$\delta_{x C S}(\mathrm{~mm})$ & 0.023 & 0.0230 \\
\hline$\delta_{y C S}(\mathrm{~mm})$ & -0.029 & -0.0283 \\
\hline$\delta_{x B Z}(\mathrm{~mm})$ & 0.031 & 0.0309 \\
\hline$\delta_{z B Z}(\mathrm{~mm})$ & -0.037 & -0.0368 \\
\hline
\end{tabular}


Table 3 Eccentricities of circular trajectories measured by DADS

\begin{tabular}{l|r|r|l|r|c}
\hline \multirow{2}{*}{ Direction } & \multicolumn{3}{|c|}{ C-axis } & \multicolumn{2}{c}{ B-axis } \\
\cline { 2 - 6 } & Radial *1 & Radial *2 & Axial & Radial *1 & Axial \\
\hline$e_{x}(\mathrm{~mm})$ & -0.0070 & 0.0010 & 0.0136 & -0.1039 & 0.0332 \\
\hline$e_{y}(\mathrm{~mm})$ & 0.0225 & 0.0193 & 0.0086 & & \\
\hline$e_{z}(\mathrm{~mm})$ & & & & 0.0016 & 0.0295 \\
\hline
\end{tabular}

Radial *1: $\quad R_{C}=100 \mathrm{~mm}$

Radial $* 2: \quad R_{C}=150 \mathrm{~mm}$

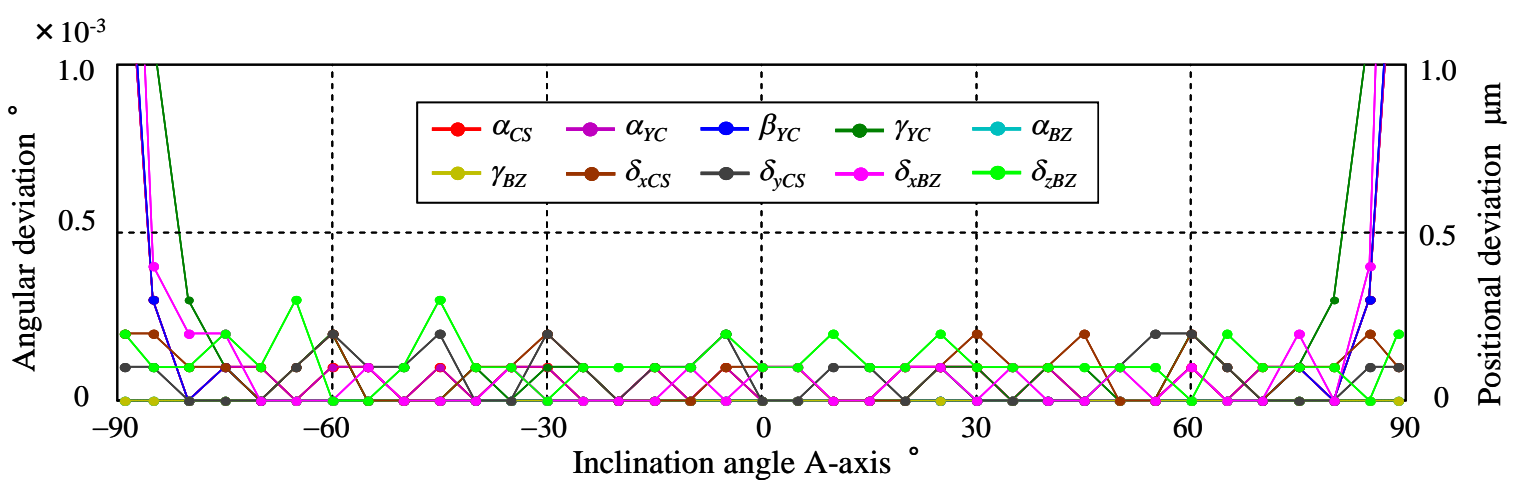

Fig.8 Influences of inclination angle of $\mathrm{C}$-axis on the identified results

を表 2 の第 3 列に示寸. 表 2 に示したように，与えた值と同定した值との差は，角度偏差で $0.0001^{\circ}$ 以下，位置偏 差で $0.7 \mu \mathrm{m}$ 以下といずれも小さな值となっており，正しく同定が行えているといえる.

\section{$6 \cdot 2$ 数値計算ソフトウェア}

数值計算ソフトウェア（MATLAB, ver. 7.9.0.529）を用いて本方法の適用限界について調べた。前節と同じ取付 け条件のもとで，モデルに幾何偏差を与えて計算した，具体的には，図 2 に定義する角度偏差と位置偏差とにそ れぞれ $0.005^{\circ}, 10 \mu \mathrm{m}$ を与え， $\alpha_{0}$ を変化させた場合に，与えたこれらの幾何偏差と同定された值との差がどのよ うに変化するかを調べた。 その結果を図 8 に示す。

図示したように, $\mathrm{C}$ 軸周りの角度偏差と $\delta_{x B Z}$ が $\alpha_{0}<-75^{\circ}, 75^{\circ}<\alpha_{0}$ のときに急激に大きくなっているものの, $-75^{\circ}$ $\leqq \alpha_{0} \leqq 75^{\circ}$ の範囲では，位置偏差で $0.2 \mu \mathrm{m}$ 以下，角度偏差で $0.0003^{\circ}$ 以下の誤差となっているのがわかる．したが って, 本研究で提案した方法は, $-75^{\circ} \leqq \alpha_{0} \leqq 75^{\circ}$ の範囲の機械に適用寸る場合には, 高精度に幾何偏差を同定でき る可能性が高いといえる.

\section{7. 結 言}

本研究では, すでに報告した傾斜したテーブル旋回軸をもつテーブル旋回形 5 軸 $\mathrm{MC}^{(11)}$ に引き続いて, 混合形 5 軸 MC で傾斜した主軸頭旋回軸をもつ形態をとりあげ，任意の主軸頭傾斜角をもつ機械に適用することを考慮 して幾何偏差と偏心量との関係を表す近似式を求め，その関係式を用いて偏差を同定する手順を明らかにした. 主な結果を要約すると次のようになる.

1) 傾斜した旋回主軸頭をもつ 5 軸 MC について，その傾斜を幾何偏差に初期值があるものとして扱うことによ って，これまでと同様に，旋回軸周りに 10 個の幾何偏差が存在するものとしてモデル化を行うことができる.

2) 対象とする 5 軸 MCにボールバーによる同時 3 軸制御運動を測定しようとすると, 傾斜軸を回転軸とする運 動では，同時 4 軸制御運動となる.

3) ボールバー測定で得られた軌跡の偏心量と幾何偏差との関係について，旋回軸の傾斜角 $\alpha_{0}$ を用いた一般式を 求め，この式を用いて 5 通りの運動から旋回軸周りに存在する全ての幾何偏差を同定することができる.

4) $\alpha_{0}=0^{\circ}$ ，すなわち従来からの構造形態の機械の場合には，偏差を同定するためには 6 通りの運動を測定する 必要がある. 
以上から，ボールバーを用いて測定した同時 3 軸及び同時 4 軸運動の偏心量から，任意の傾斜角度をもつ旋回 主軸頭と回転テーブルとを備えた混合形 5 軸 MC の幾何偏差を同定するために必要な一般式を導くことができた. これによって，直交座標系に平行に配置された旋回軸で回転する混合形 5 軸 MC と同列に扱うことができるよう になったといえる。

\section{謝 辞}

本研究の一部は，科学研究費補助金基盤研究(B)（No. 20360063）の補助を受けて行ったものであり，関係各位 に感謝する.

\section{文献}

(1) 崔 成日, 東山憲司, 堤 正臣, Dassanayake, K.M.M., 旋盤形複合加工機に存在する幾何偏差同定方法, 日本機械学会 論文集 C 編, Vol.75, No.750, (2009), pp.476-483.

(2) Tsutsumi, M. and Saito, A., Identification and compensation of particular deviations of 5-axis machining centers, International Journal of Machine Tools and Manufacture, Vol.43, (2003), pp.771-780.

（3）垣野義昭，井原之敏，佐藤浩毅，大坪 寿，NC 工作機械の運動精度に関する研究（第 7 報） - DBB 法による 5 軸制 御工作機械の運動精度の測定一精密工学会誌, Vol.60, No.5, (1994), pp.718-722.

（4）坂本重彦，稲崎一郎，塚本頴彦，市来崎哲雄，ボールバーによる五軸マシニングセンタの組立誤差同定方法，日本 機械学会論文集 C 編, Vol.63, No.605, (1997), pp.262-267.

(5) Mahbubur RMD, Heikkala J, Lappalainen K, Karjalainen JA. Positioning accuracy improvement in five-axis milling by post processing. International Journal of Machine Tools \& Manufacture;Vol.37, No.2, (1997), pp.223-236.

(6) Bohez, E LJ., Ariyajunya, B., Sinlapeecheewa, C., Shein, T.M.M., Lap, D.T., and Belforte, G. , Systematic geometric rigid body error identification of 5-axis milling machines, Computer-Aided Design, Vol. 39, (2007), pp.229 -244.

(7) Ibaraki, S., Sawada, M., Matsubara, A., Mori, M., Kashihara, K. and Kakino, Y., Measurement of dynamic angular error of rotation axis of a universal spindle on integrated machine tools by using the ball bar method, Journal of Japan Society of Precision Engineering, Vol.73, No.5, (2007), pp.583-587.

(8) Uddin, M. S, Ibaraki, S., Matsubara, A. and Matsushita, T., Prediction and compensation of machining geometric errors of five-axis machining centers with kinematic errors, Precision Engineering, Vol. 33, Issue 2,(2009), pp.194-201.

(9) Zargarbashi, S.H.H. and Mayer, J.R.R., Single setup estimation of a five-axis machine tool eight link errors by programmed end point constraint and on the fly measurement with capball sensor, International Journal of Machine Tools and Manufacture, Vol.49, Issue 10, (2009), pp.759-766.

(10) Lei, W.T., Paung, I.M. and Yu,. C. C., Total ballbar dynamic tests for five-axis CNC machine tools, International Journal of Machine Tools and Manufacture, Vol.49, Issue 6, (2009), pp. 488-499.

(11) 深山直記, 佐伯智之, 崔 成日, 堤 正臣,テーブル旋回形 5 軸制御マシニングセンタの幾何偏差同定方法の一般化, 日本機械学会論文集 C 編, Vol.75, No.756,(2009), pp.2335-2342.

(12) 齋藤明徳, 堤 正臣, 牛久健太郎,5 軸制御マシニングセンタのキャリブレーション 一 同時 3 軸制御運動による位 置偏差および角度偏差の推定方法 — 精密工学会誌, Vol.69, No.2, (2003), pp.268-273.

(13) 稲崎一郎, 岸浪健史, 坂本重彦, 杉村延広, 竹内芳美, 田中文基, 工作機械の形状創成理論, 養賢堂, (1997), p.98.

(14) Weikert, S., R-test, a new device for accuracy measurements on five axis machine tools, Annals CIRP, Vol. 53, No.1, (2004), pp.429-432.

(15) 内海敬三, 小杉達寛, 齋藤明徳, 堤 正臣，5軸制御マシニングセンタの静的精度測定方法 ( 基準球と変位計を用 いた測定方法 )，日本機械学会論文集C編，Vol.72, No.719, (2006),pp.2293 2298.

(16) Dassanayake, K.M.M., Tsutsumi, M. and Saito, A., A strategy for identifying static deviations in universal spindle head type multi-axis machining centers, International Journal of Machine Tools and Manufacture, Vol.46, (2006), pp.1097-1106. 